\title{
A conceptual model and detailed framework for stress-related, strain- related, and overuse athletic injury
}

\author{
Judd T. Kalkhoven $^{1}$, Mark L. Watsford ${ }^{1}$, and Franco M. Impellizzeri ${ }^{1}$ \\ ${ }^{1}$ Faculty of Health, University of Technology Sydney
}

October 14, 2019

\begin{abstract}
A multitude of athletic injuries occur when the various tissues that make up the human body experience stresses and strains that exceed their material strength. The precise amount of stress and strain that any given tissue can withstand is determined by the mechanical properties and resultant strength of that particular tissue. These mechanical properties are directly determined by an individual's physiology and acute regulation of these properties. A number of theoretical frameworks for athletic injury occurrence have been proposed, however, a detailed conceptual framework for injury aetiology that considers the interplay between the physiological and mechanical factors and outlines the causal pathways to injury is needed. This will guide injury research towards a more thorough investigation of causal mechanisms and understanding of risk factors. Further, it is important to take into account the considerable differences in loading patterns which can result in varying injury outcomes such as acute stress-related, strain-related, or overuse injury. Within this article a simplified conceptual model of athletic injury is proposed along with a detailed, evidence-informed, conceptual framework for athletic injury aetiology that focuses on stress-related, strain-related, and overuse injury.
\end{abstract}

Keywords: Conceptual injury model; detailed injury framework; stress-related injury; strain-related injury; overuse injury

DOI: http://dx.doi.org/10.31236/osf.io/vzxga

Citation: Kalkhoven, J. T., Watsford, M. L., \& Impellizzeri (2019). A conceptual model and detailed framework for stress-related, strain-related, and overuse athletic injury. SportRxiv. Doi: 10.31236/osf.io/vzxga

Corresponding author: Judd Kalkhoven (Judd.kalkhoven@uts.edu.au $)$ This work is a preprint and has yet to be peer-reviewed.

All authors have read and approved this version of the manuscript for pre-print.

Twitter handles: @KalkhovenJudd / @ francoimpell 


\section{TABLE OF CONTENTS}

1. Introduction

2. Conceptual model for athletic injury

3. Detailed framework for stress-related, strain-related, and overuse injury

3.1 Part A: Physiology of an individual

3.2 Part B: Tissue-specific strength

3.3 Part C \& D: Tissue loading: stress and strain experienced

3.4 Part E \& F: Athletic injury or possible adaptation

3.4.1 Acute/macro stress and strain related injury

3.4.2 Microdamage, tissue fatigue and overuse injury

3.4.3 Possible physiological adaptations

4. Implications of the framework

4.1 Implications for athletic injury research hypotheses and questions

4.2 Implications for research methodologies and data collection procedures

5. Conclusion

\section{Key Points}

1. A detailed framework outlining the causal pathways of specific risk factors for injury occurrence has not been established. As a consequence, a multitude of injury research has been conducted with little regard for the specific mechanisms and causal pathways of injury, basing such enquiry on spurious associations and relationships. As such, a detailed injury framework is needed to help facilitate and align future research more closely to the fundamental mechanisms and causes of injury.

2. The vast majority of contact and non-contact athletic injuries occur as a result of exposure to either a singular, or repetitive, stresses and strains, including overuse injury. As such, there is scope for many athletic injuries to be included within a single conceptual framework centred around stress and strain which is proposed below.

3. Mechanically, the core principle surrounding the cause of stress-related and strain-related injury is the exceeding of the load tolerance or strength of a tissue due to an applied load. All risk factors associated with stress-related or strain-related athletic injury must do so by influencing either the resilience of a specific tissue subject to injury, the load applied to that tissue, or both. Further, considerable differences in loading patterns and the tissue involved can result in a variety of outcomes regarding injury type such as acutestress or strain-related injury or overuse injury.

\subsection{INTRODUCTION}

A number of frameworks for athletic injury have been presented in the literature [1-8]. These frameworks typically remain general in nature and do not provide detailed explanations of causal relationships with injury. Bertelsen et al. [2] recently presented an injury framework specific to running-related injury and suggested that sport-specific frameworks were needed to expand understandings of injury mechanisms. Although sport-specific injury frameworks may hold value, particularly for addressing contextual factors for injury within specific sports, an alternative approach may be to centre on the specific types of injury as mechanistic similarities may be present across a number of sports with the only differences being the context of the sport being participated in. One such example is the recent framework for overuse injury presented by Edwards [8]. To understand the cause of injury it is important to address the core mechanical principles surrounding material failure. As a generalised concept of mechanical failure, failure occurs when the strength of a structure or material is exceeded by excessive stress and strain induced by either the application of a singular high-magnitude stress or alternatively repeated applications of load at some percentage of the material's ultimate strength [9]. Considering that biological tissue is also a material, many of the same fundamental principles of material fatigue and failure are still highly applicable. However, it is important to acknowledge the physiological environment in which tissue resides, incorporating tissue remodelling and recovery. As such, considering that the vast majority of contact and non-contact athletic injuries occur as a result of exposure to either a singular, or repetitive, stresses and strains [8, 10-12], including overuse injury [8], there is scope for many 
athletic injuries to be included within a single conceptual framework centred around stress and strain. Injuries that fall outside this grouping, or that require a more complex research framework, such as concussion and traumatic brain injury, may require their own specific injury frameworks given the varied circumstances and mechanisms. Within this context, "stress" specifically refers to the internal forces experienced by a structure and can be further defined as the force per unit of area, while "strain" is defined as the amount of deformation or length change in the direction of an applied force [13, 14].

Injury occurrence continues to be a significant burden on the athletic population with a range of stress-related injuries, strain-related injuries, and overuse injuries commonly occurring within the sporting arena. Although the amount of strain experienced by a structure is proportional to the amount of stress experienced, a concept known as Hooke's law [15], and mechanical failure occurs at a specific point on a stress-strain curve, some injuries align more closely to the stress experienced by a structure, while others align more closely to the strain. Therefore, it seems prudent to emphasize that stress and strain are fundamentally different phenomena and should be considered as such. This allows for a more effective encapsulation of the interaction between the physiological and mechanical factors contributing to injury within the specific context of being either a stress-related or strain-related injury, facilitating research seeking to determine methods to protect against such injuries. Common stress-related injuries include acute bone fractures, overuse bony stress fractures and joint injury while common strain-related injuries include strain or overuse injuries of the musculotendinous unit (MTU). Injuries to the MTU are consistently the most prevalent time-loss injury in a large number of sports including soccer [16, 17], Australian football (AFL) [18, 19], tennis [20] and others [21, 22]. Considering the multitude of injury types that exist within sport, superior understandings of the physiological and mechanical contributions to different injuries would better facilitate the generation of specific and appropriate research questions, and the development of causal structure that can be specifically examined to support causal associations. This is essential to the development of preventative interventions and causal understandings of injury factors. To date, a multitude of research exists in the field of sport-related injury, with a range of studies exploring an array of factors supposedly associated with athletic injury occurrence. Many of these factors, although sometimes associated with injury, are not necessarily the causes of injury. To make causal inferences, other than using appropriate statistical methods, it is necessary to develop a causal structure of the phenomenon under study, which is based on structural knowledge (e.g. a conceptual framework).

Mechanically, the core principle surrounding the cause of stress-related and strain-related injury is the exceeding of the load tolerance or strength of a tissue due to an applied load, a concept that has been asserted previously within the literature [1,3]. All risk factors associated with stress-related or strain-related athletic injury must do so by influencing either the resilience of a specific tissue subject to injury, the load applied to that tissue, or both. Typically, this is achieved by impacting the physiological composition and functioning of the human body, and consequently the mechanical properties as well, or the external and internal forces that contribute to the specific structural stresses and strains experienced by an individual, or all of the above. Many studies do not fully explore or acknowledge the mechanical contributions to injury and are typically concentrated on injury associations, neglecting the interactions between structural load tolerance and load application. This limits the capability of thoroughly identifying and understanding risk factor contributions to injury causation. The physiological and mechanical contributions to injury are not mutually exclusive, and as such, it is important that future research shifts towards the active identification of how specific risk factors influence both the physiological and mechanical contributions to injury, the interactions between the two, and their influence on tissue resilience and load applications.

This paper proposes a simplified conceptual model of athletic injury along with a detailed framework for stress-related, strain-related and overuse injury. These frameworks have been created with the intention of shifting injury research away from solely establishing associations with injury and HARK-ing (hypothesizing after the results are known), and towards attempting to establish direct causation by exploring how specific stress, strain, or overuse risk factors contribute to the causal pathways of injury occurrence. Further, this framework highlights the importance of considering that specific risk factors may influence the physiological and mechanical properties of an individual along with the external forces and specific loadings experienced by certain tissues in the body. In doing so, these components have an influence on both load tolerance and load application. As for all frameworks, the specific components and links should be examined through specific studies and modified or 
dismissed as needed. This is a normal step in the scientific process.

\subsection{CONCEPTUAL MODEL FOR ATHLETIC INJURY}

The conceptual model of athletic injury presented below (Figure 1) has 6 levels that are centred upon injury. The outer/first level includes all causal contextual factors. For a contextual factor to be considered causal it must influence in some capacity either the resilience of a specific tissue subject to injury, the load applied to that tissue, or both. To achieve this, the contextual factor in question must exert its effects on the second level of the framework which consists of an individual's physiological profile and functioning, mechanical properties, and the force applied to the body and the various tissues within. It is important to consider that some biological tissues, such as muscle, can readily change mechanical properties through muscle activation [10,23]. All three outer ring components interact to determine the third level of the model which includes the load tolerance of the structures subject to injury and the loading applied. As a core generalised concept of injury, when the load applied to a specific structure exceeds the load tolerance, injury results. The fourth level is mechanically more specific than the third, incorporating the internal stress and strain experienced by specific tissues whilst also separating the structural load tolerance into tissue-specific strength. The fifth level further scrutinizes this aspect, assigning a time frame by separating into the immediate and repetitive stresses and strains which must be considered when investigating various types of injury. Considerable differences in loading patterns can result in a variety of outcomes regarding injury type such as acute-stress or strain-related injury or overuse injury. The final level of the model refers to actual injury occurrence. When the stress or strain experienced, whether immediate or repetitive in nature, exceeds the strength of a particular tissue, failure occurs and injury results.

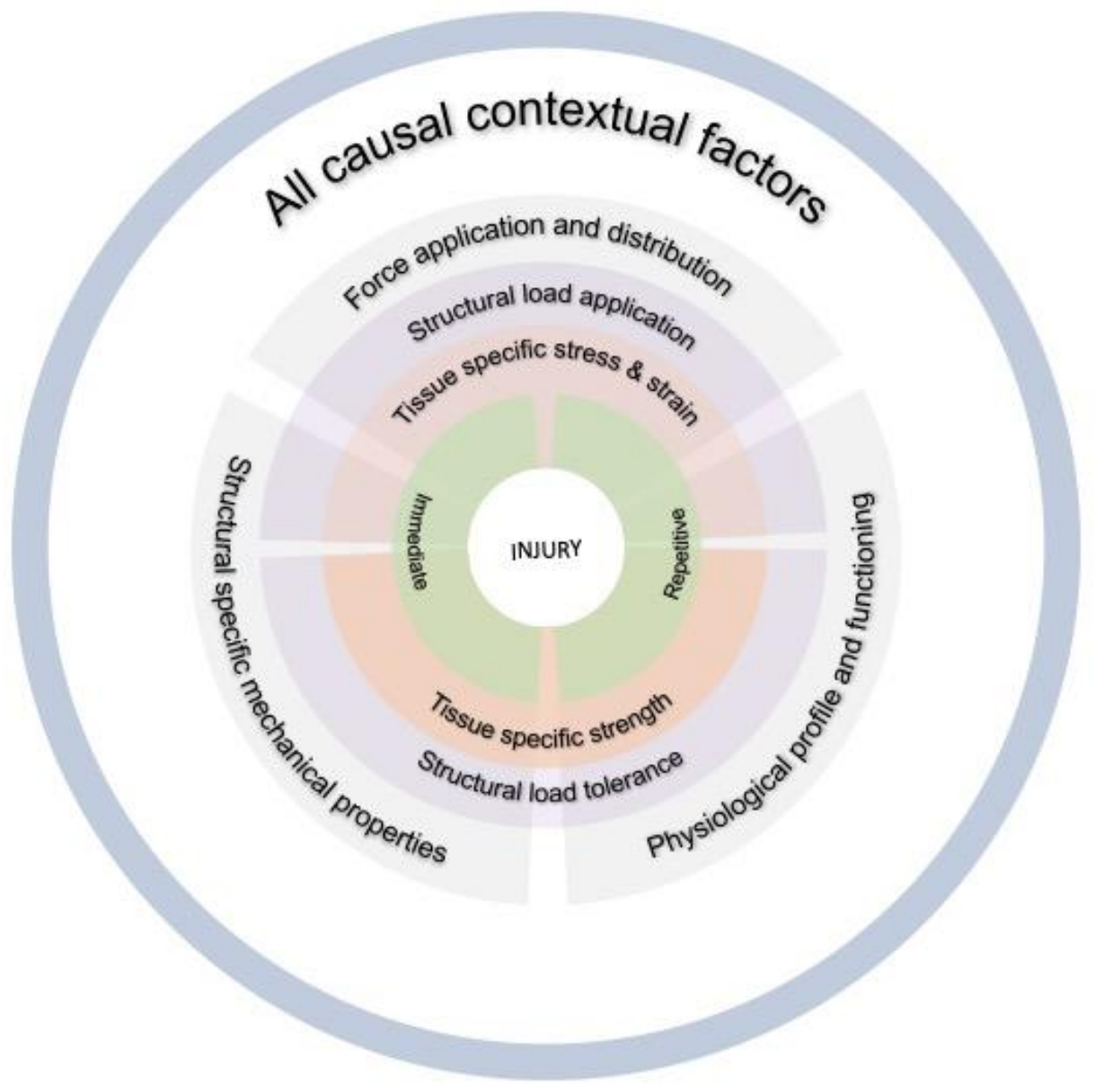

FIGURE 1: A conceptual model for athletic injury 
There are a number of key considerations that warrant attention if thorough understandings of the contributions of potential risk factors to injury are to be developed. These considerations will help facilitate the formation of appropriate risk mitigation strategies. Importantly, researchers must determine whether a potential risk factor simultaneously influences the load tolerance of the various tissues prone to injury during a particular activity, and the loadings experienced by that tissue. This is an important consideration as injury results from a complex interplay between tissue strength and tissue loading and there may be injury risk mitigation strategies that reduce the load tolerance of a particular tissue or structure but minimally influence or even improve injury risk status through a concomitant lessening of applied loads. Although an improved injury risk status appears beneficial, in such a scenario a reduction in athletic capacities and hindered performance outputs may result. As a generalized concept, this may occur if the load application reduces to a greater extent relative to the load tolerance, decreasing the likelihood of the tissue strength being exceeded. Thorough understanding of this interplay is required to form appropriate injury risk mitigation strategies that do not detrain athletes or diminish tissue resilience but improve injury risk status. Using detraining in athletes required to sprint as an example, an athlete may reduce muscle mass, maximal force outputs and sprint velocities with detraining [24-27], resulting in diminished hamstring resilience and reduced hamstring loadings due to lowered force production and sprinting capabilities. Such a scenario may decrease injury risk of the hamstrings with an undesirable corresponding negative impact on performance due to the athlete's inability to produce as large force outputs and sprint velocities. An optimal approach for athlete development would be to implement protocols that enhance the resilience of various tissues subject to injury to enable athletes to tolerate the loading associated with heightened performance outputs. Further, some strategies that develop tissue resilience may also provide performance benefits [28, 29], emphasizing the importance of understanding the relationship between load tolerance and load application and the consequences of the strategy adopted for influencing these two components.

A further important consideration related to the conceptual model is ensuring that researchers have a thorough understanding of how individual components that contribute to injury interact with other factors that underpin the load tolerance of a particular structure or tissue and the loads being applied. For example, when assessing muscular resilience, the use of a single property such as MTU stiffness or active strength as a proxy for load tolerance may hold research value, however, it may also produce mixed research outcomes if other mechanical factors contributing to muscular load tolerance are not accounted for such as muscle fibre or fascicle lengths and muscle activation timing which may have substantial implications for the absolute stress and strain tolerances of the tissue for a given point in time. Researchers must seek ways to better quantify the material strength of the various tissues subject to injury, incorporating the multitude of factors contributing to tissue resilience. Further, technological breakthroughs allowing for the better quantification of specific tissue loadings would allow for thorough examinations of the inter-play between tissue load tolerances and load applications, assisting in the examination of injury causation. To help facilitate this further a detailed-framework for stressrelated, strain-related, and overuse injury is presented below.

\subsection{DETAILED FRAMEWORK FOR STRESS- RELATED, STRAIN-RELATED, AND OVERUSE INJURY}

To build on the rings of the conceptual model and provide an enhanced depth of understanding, a detailed framework underpinning stress-related, strain-related, and overuse athletic injury is presented in Figure 2. Within the figure, Box A represents the factors contributing to the physiology of an individual highlighted in the outer ring of the conceptual model. Box $\mathrm{B}$ represents the immediate and chronic mechanical properties and tissue-specific strengths determined by an individuals physiology and acute mechanical regulation. Box $\mathrm{C}$ represents the forces experienced by specific tissues within the body. Box $\mathrm{D}$ is reflective of the third layer of the conceptual model and represents the amount of stress and strain experienced within a particular tissue, determined by the mechanical properties of the body and its various tissues, the applied forces, and specific tissue loadings which makes up junction 1. Junction 2 is the interplay between the strength of a particular tissue at risk of injury and the the stress and strain experienced by the tissue. Box E represents injury occurrence. Acute stress-related or strain-related injury occurs when the load applied to a specific tissue exceeds the strength of that tissue. If the tissue strength is not exceeded and acute stress-related or strain-related injury does not occur then physiological adaptations may result, as depicted by Box F. For overuse injury to present, a 


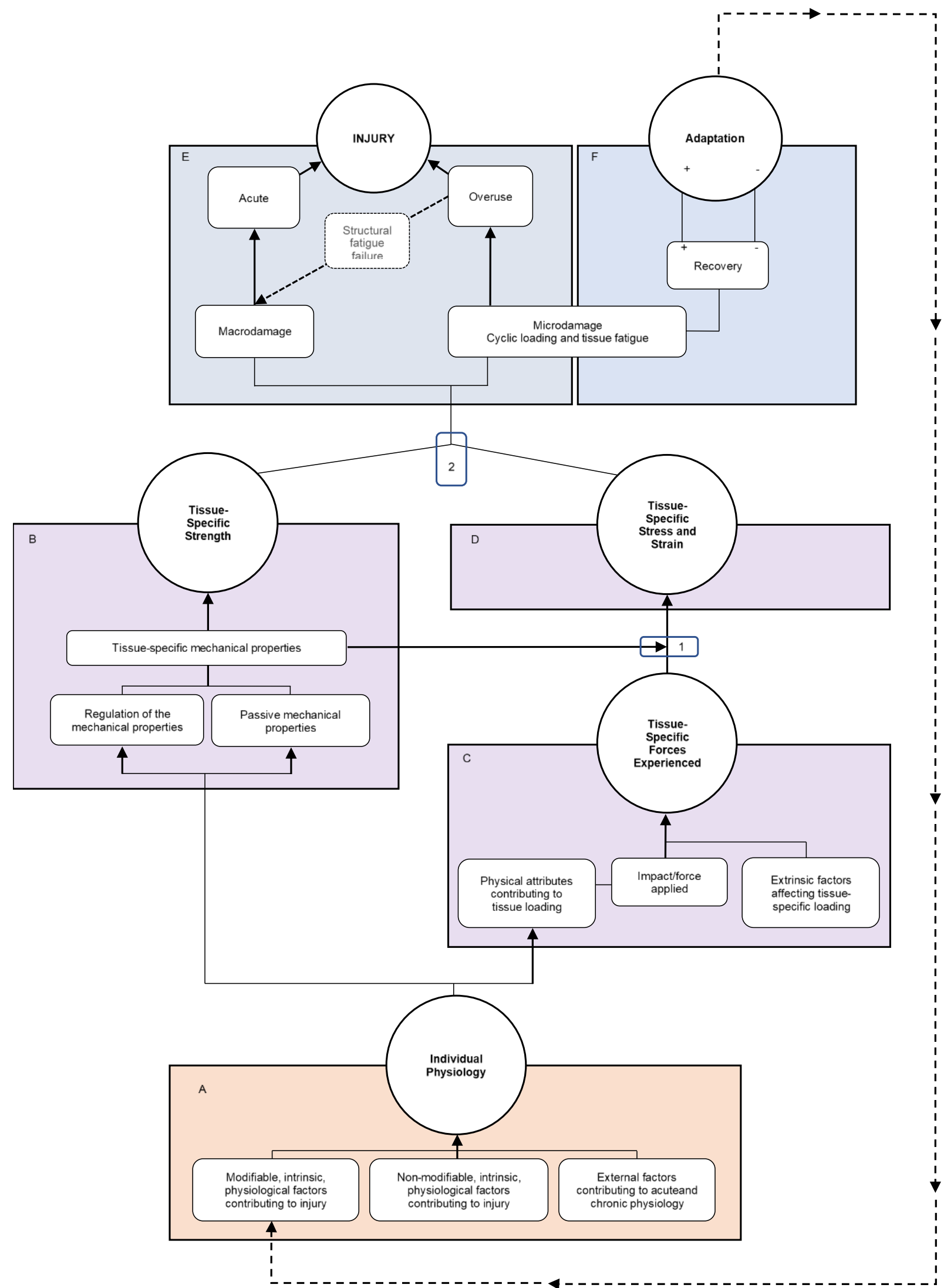

FIGURE 2: A detailed framework for stress-related, strain-related, and overuse injury 
considerably different mechanical loading pattern leading to microdamage and tissue fatigue and eventual overuse injury must be experienced. In the proceeding text, the various groupings of the framework will be explained in detail.

\subsection{Part A: Physiology of an individual}

The physiological make up of an individual determines the mechanical properties of the body along with the physical performance competencies of an athlete. As such, physiology, to a large extent, dictates the forces an athlete is exposed to along with the load capacities of the various structures of the body. For these reasons individual physiology forms the base of the framework. A range of injury risk factors contribute to, or are strongly associated with physiology. These factors influence injury risk by either impacting the load tolerance of specific tissues, the loading of specific tissues, or both. Within the framework, these factors have been separated into modifiable intrinsic physiological risk factors contributing to injury, nonmodifiable intrinsic physiological risk factors contributing to injury, and all external factors contributing to acute and chronic physiology.
A number of modifiable intrinsic physiological factors have been associated with athletic injury. Examples of injury risk factors that fit within this category are body composition [30-37], bone mineral content [38-40], muscle structure including fascicle length [41-46], optimal muscle length for force production [46], and tendon structure [47, 48] among others. Some nonmodifiable, intrinsic physiological factors that have an association with injury include age [34-37, 40, 49-51], gender [36, 51, 52], height [34, 53-56], previous injury [36, 37, 40, 56-67], menstruation [39, 40, 68, 69], blood type [70], and condyle width [71, 72] among others. The third category at this level includes external factors that are known to influence physiology whether chronically or acutely. One such factor that has been given significant attention within the literature is external training workload with a body of research trying to associate running distance $[30,51,53,54,56$, 57, 63, 67, 68, 73-80], duration [34, 50, 81, 82], frequency $[35,51,52,56,73,78]$, pace and interval $[30,50,53,59,65,78,82,83]$ with injury risk. Other factors explored within the literature include training method [42, 84-90], nutritional intake [39, 40], warm up, cool down, and stretching [91], medications [39, $40,68,69,92]$ and sleep [93-95] among others.

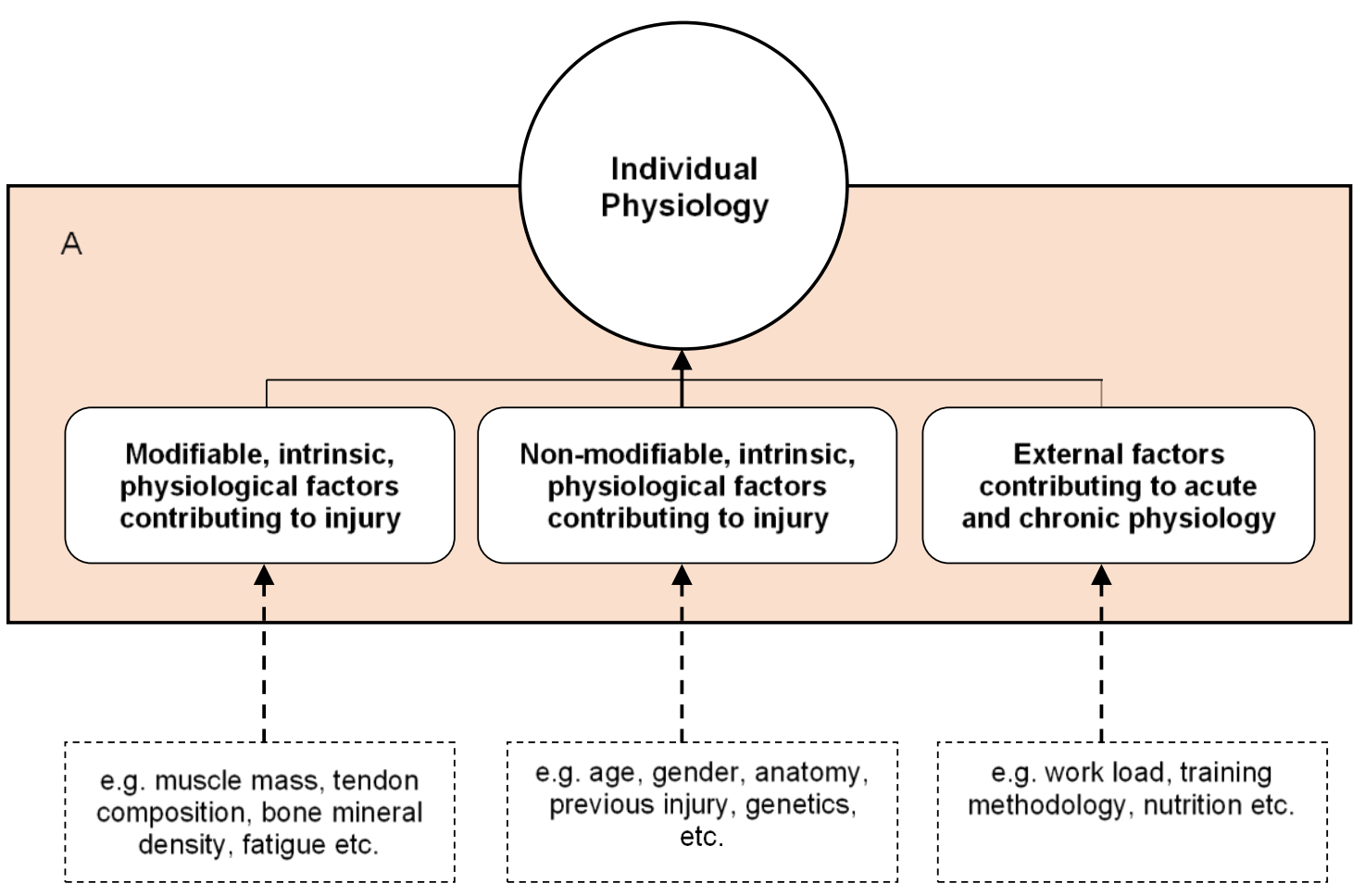

FIGURE 3: Part A of the detailed framework 


\subsection{Part B: Tissue-specific strength}

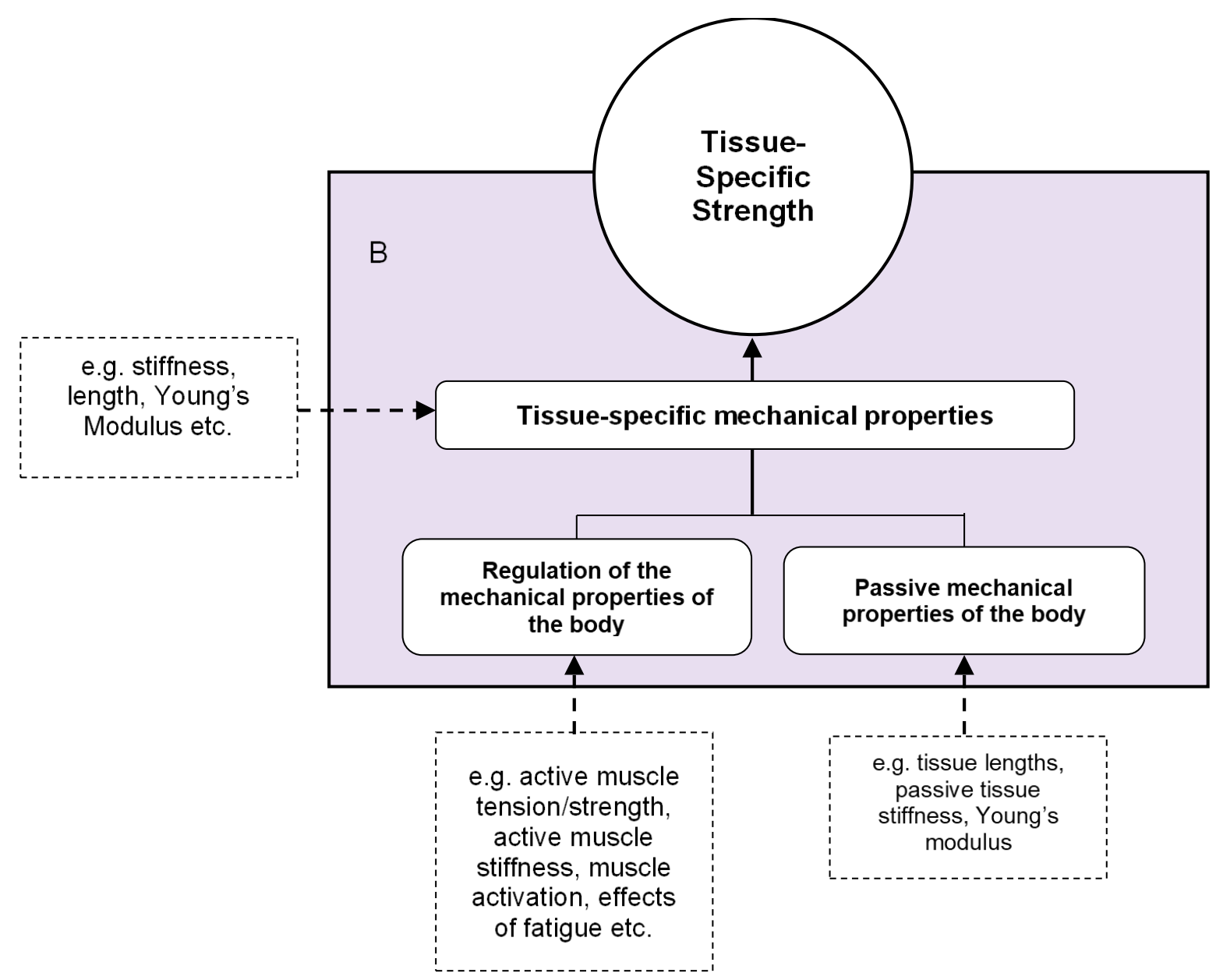

FIGURE 4: Part B of the detailed framework

The human body is comprised of a range of tissues, including bone, tendon, ligaments, and musculature which are commonly exposed to injury during sporting activity. Although they all largely contribute to a system of functioning and load management, each possess their own specific strengths that when exceeded, result in failure of the tissue. The mechanical composition and physiological functioning of these tissues dictate their strength and their role in accommodating stress and strain during various activities which influences the failure risk for a given activity. As such, proper understandings of these tissues and how the factors exposing them to injury influence their physiological functioning and mechanical characteristics is of utmost importance for understanding injury causation. Box B encapsulates all the mechanical properties of the human body that contribute to the specific strengths of the various tissues subject to injury. The mechanical properties of these tissues are a direct result of an athletes physiological make up. As such, alterations to physiology directly influence the mechanical properties exhibited, and consequently affect tissue resilience. This relationship is commonly neglected within the literature and forms the link between part A and part B of the framework.

There are a multitude of research studies investigating how changes in physiology result in changes to the mechanical properties of the body. For example, tendons have been shown to increase in stiffness, Young's modulus, and cross sectional area in response to various training stimuli [47, 96-102] while Kubo et al. [103] reported that plyometric training may influence the maximal elongation of tendons whilst maintaining stiffness, suggesting an alteration to the internal physiology of the tendons. Similarly, increases 
in muscle hypertrophy, strength, and subsequently active stiffness and Young's modulus in response to load exposure have been consistently reported [104106]. Many studies have shown similar changes to the mechanical properties of other tissues such as bone whereby increases in bone tissue and bone mineral density are typically observed in regions of high mechanical stress, providing an efficient means for improving bone stiffness and strength [107, 108].

Many tissues in the body, such as bone and tendon, cannot readily alter their mechanical properties and therefore do so through chronic physiological adaptation. In contrast, the mechanical properties of other tissues and structural systems within the body, such as joints, limbs and musculature can be altered acutely. This is predominantly achieved through muscle spindle [109, 110] and Golgi tendon organ activation [109, 110] and more generally, muscle activation $[23,109,110]$. For example, the stiffness of the MTU has shown to increase as a result of increased muscle activation, subsequently increasing the stress tolerance of the musculature and reducing the amount of strain experienced for a given stress [23]. As such, many physiological injury risk factors are associated with injury through their influence on muscle activation and function and the resulting mechanical properties that present. Factors known to have such influence include acute fatigue [111], acute glycogen depletion [112-114], and muscle acidification [111] among others. These factors are important to consider as any factors that impair muscular functioning inevitably reduce muscular resilience for any given point in time and may also increase the stress imposed on other bodily tissues.

\subsection{Part C \& D: Tissue loading: Stress and strain}

In material sciences, failure occurs when the strength of any given material is exceeded by excessive stress and strain induced by either the application of a singular high-magnitude stress or alternatively repeated applications of load at some percentage of the material's ultimate strength [9]. Considering that

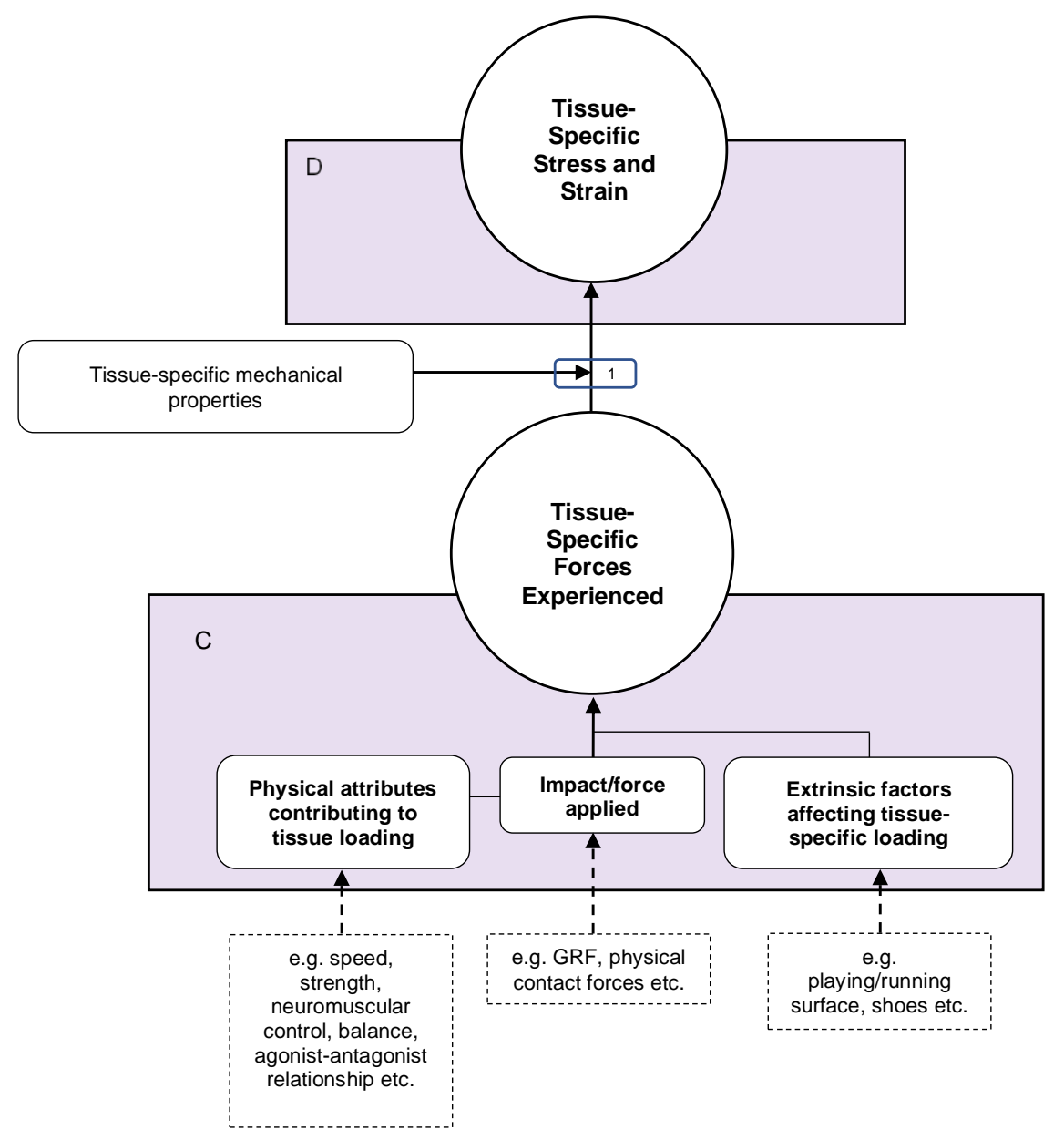

FIGURE 5: Part C \& D, and junction 1 of the detailed framework 
biological tissue is also a material, albeit within a complex physiological environment that incorporates tissue remodelling and recovery, the majority of athletic injuries occur as a result of excessive stress and strain, whether experienced acutely, resulting in acute stress or strain related injury, or over time, resulting in overuse injury. Although the relationship between stress and strain are proportional for any given material with consistent mechanical properties (Hooke's law), some biological tissues such as muscle, can readily alter the relationship between stress and strain (Young's modulus) by changing mechanical properties, specifically stiffness. The magnitude of stress and strain experienced by a particular tissue is determined by the interaction between the force applied to a specific tissue and the mechanical properties of that tissue, labelled as junction 1 in the framework. For a material or tissue to experience stress and strain, the primary mechanical contributors to material failure, force, must first be applied. The main contributors to these forces are captured in Part C of the framework. A number of physical attributes contribute to, and have been associated with injury by influencing aspects of structural loading. Physical attributes that influence injury risk such as muscular strength [115-118], agonist-antagonist muscle relationships [116, 119125], power production capabilities and sprint speeds
[125, 126], balance [127, 128], neuromuscular control [129-131], and movement mechanics and technique [132-134], among others, all contribute to the loading of specific structures within the body. Other external factors including ground reaction force $[12,135,136]$, physical contacts [137-140], running surface [141, 142] and shoe type [143] all reportedly contribute to injury by influencing the forces experienced and the distribution of these forces across various tissues. These forces then interact with the physiologically determined and acutely regulated mechanical properties of the body and its various tissues which determines the stress and strain experienced, captured in Part D of the framework. Interestingly, despite excessive stresses and strains being the primary causes of athletic injury, these mechanical factors also provide important stimuli for positive physiological and mechanical adaptation when appropriately managed. As such, a distinction between excessive stress and strain and appropriate exposure is provided in part $\mathrm{E}$ and $\mathrm{F}$ of the framework.

\subsection{Part E \& F: Athletic injury or possible adaptation}

\subsubsection{Acute/macro stress and strain related injury}

A range of tissues within the body that are subject to

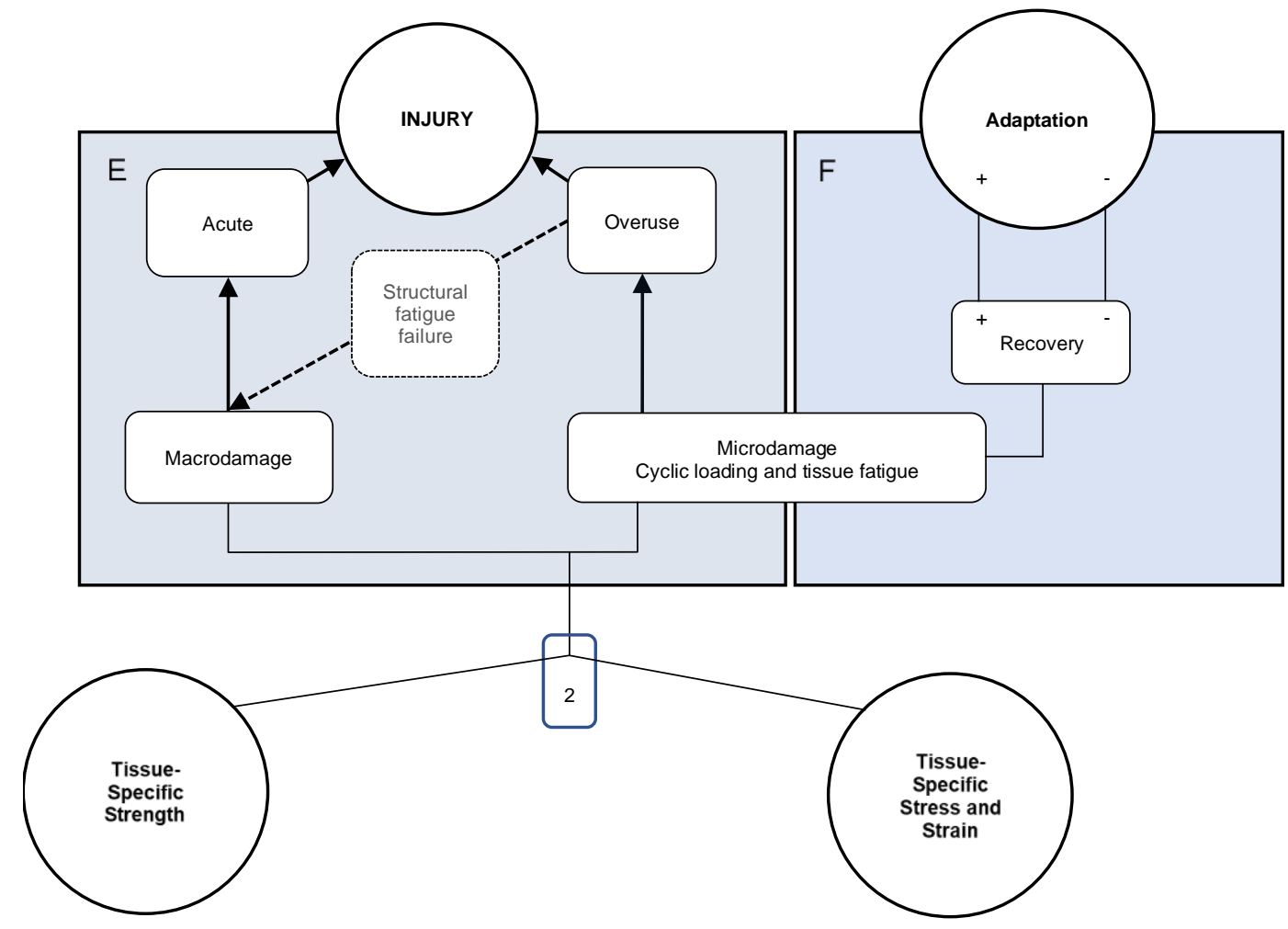

FIGURE 6: Part E \& F, and junction 2 of the detailed framework 
injury possess their own material strengths. Strength is the capacity of a particular structure, material, or tissue to withstand an applied load. When the stress and strain experienced exceeds the strength of a particular tissue, structural failure occurs, resulting in acute stress or strain related injury. Junction 2 in the framework is representative of the interplay between the stress and strain that a particular tissue experiences and the strength of that tissue. Although macroinjury and tissue failure are synonymous, within the human body tissue microdamage may provide an important stimuli for positive physiological and mechanical adaptation. However, the defining point at which structural damage is considered excessive and injury presents remains somewhat ambiguous, particularly in musculature [144]. As such, tissue strength appears to be the appropriate term for this concept. Although stress and strain are proportional to one another (Hookes law), injury to certain tissues is typically more aligned to either the stress encountered, or strain experienced. This is due to the various mechanical properties that exist between structures along with the capacity of certain tissues, such as musculature, to alter Young's modulus [145-149]. It is commonly understood that muscle injury is more closely related to the strain experienced rather than the stress $[10,11$, 150]. Specifically, it appears that muscle injury occurs when exposed to strain under conditions of very high muscle tensions $[10,11,150-153]$. Conversely, overuse stress fractures or acute injury of bone are more aligned with excessive stress being experienced by the bone $[154,155]$. The strength of a given material or tissue is specific to the type of loading experienced, with different types of strength existing depending on the nature of the forces applied. For example, compressive strength, tensile strength, impact strength, and fatigue strength are all different strengths that contribute to the overall load tolerance of a particular structure. For the purpose of this framework the exceeding of fatigue strength (fatigue failure) follows the cyclic loading and overuse injury pathway.

\subsubsection{Microdamage, tissue fatigue and overuse injury}

When the strength of a particular tissue within the body is exceeded, injury occurs. However, the type of injury is dependent upon the nature of the loading pattern experienced. Recently, Edwards [8] proposed that overuse injuries should be modelled as a mechanical fatigue phenomenon as it appears that they occur when the tissue in question is exposed to repetitive cyclic loading that exceeds its repairability [156-158]. This leads to progressive tissue fatiguing, that if continued, results in failure [159-161]. Within the human body, mechanical fatigue is defined as microstructural damage, or microdamage, in response to cyclic or repetitive loading [8] and is characterized by the accumulation of tissue damage and the progressive diminishment of structural stiffness and strength [8]. The nature of the fatigue induced microstructural damage varies between structures with tendon damage presenting as kinked fibers or localized fiber dissociation [162] while bone presents as linear microcracks [163].

To describe the number of loading cycles to failure for a particular material, a stress-number of cycles curve ( $\mathrm{S}-\mathrm{N}$ curve), otherwise known as a Wöhler curve, is commonly used [164]. It is through the general principles of the S-N curve and structural fatigue that the running-related injury framework of Bertelson et al. [2] can be enhanced. Within their model, injury occurs when the cumulative load, expressed as the sum of the stride-specific loads that a certain musculoskeletal structure is exposed to during a single running session [165], exceeds the load tolerance of the structure. Although the quantification of cumulative load may hold value for practitioners and researchers alike, utilization of cumulative load as a surrogate for injury risk is flawed as the relationship between cumulative load and cumulative damage is non-linear, an important concept highly emphasized by Edwards [8]. The cumulative damage that a tissue experiences may vary considerably depending on whether the cyclic loading experienced consists of a smaller number of high magnitude loads (low cycle loading) or a larger number of low magnitude loads (high cycle loading). For a given cumulative load, the loading pattern consisting of relatively higher magnitude loads would be expected to induce considerably greater amounts of cumulative damage when compared to the high cycle loading, as per the Palmgren-Miner rule [166, 167]. To capture material fatigue and the interaction between load magnitude and number of cycles, a number of validated methods of predicting damage accumulation in materials with variable loading regimens similar to those typically experienced by musculoskeletal tissues have been formed with the Palmgren-Miner rule being one such example [166, 167]. Although detailed exploration of these methods for predicting damage accumulation is outside of the scope of this review, it is important to acknowledge that the Palmgren-Miner rule is an approximation that does not account for localised stress concentration or changes in molecular orientation $[167,168]$. For a more detailed examination of this concept the reader is directed to the framework of Edwards [8] and the systematic review by Gallagher $\&$ Heberger [169]. When considering cumulative tissue 
damage, it is important to acknowledge the role of recovery in damage removal, remodelling, and adaptation that takes place in biological tissues during rest and recovery.

\subsubsection{Possible physiological adaptations}

If tissue strengths are not exceeded and the loads applied do not result in the beginning stages of structural fatigue failure or overuse injury, a number of possible acute and chronic physiological changes may still occur. Some examples of physiological and mechanical changes that may present acutely include structural fatigue and reductions in mechanical stiffness [170, 171], acute fatigue [111], glycogen depletion [112-114], muscle acidification [111], and changes to muscle ultrastructure and force production [150, 153, 172-174] among others. Although these acute changes may have detrimental short-term effects, adequate recovery may provide positive long-term physiological and mechanical adaptations including muscle hypertrophy and increases in strength [175, 176], tendon adaptation [177, 178], and bone adaptation [179, 180]. However, an emphasis on recovery is important as inadequate recovery may result in a diminishment of structural and tissue resilience and a subsequent increase in injury risk. As such, proper understandings of the precise mechanisms that induce positive physiological adaptations or injury are required as the identification of the defining point at which positive physiological adaptations are no longer possible and injury occurs remains somewhat elusive. The positive or negative physiological adaptations that can potentially occur in part $\mathrm{F}$ feeds back into the first box of Part A located at the beginning of the framework.

\subsection{IMPLICATIONS OF THE FRAMEWORK}

This framework for injury occurence facilitates understandings of specific mechanisms of injury, namely stress-related and strain-related acute and overuse injuries. It sets a precedent for future research to centre around specific mechanisms and causal pathways of injury rather than base such inquiry on spurious associations and relationships. Further, this framework has been created with the intention of shifting the focus of athletic injury research towards the investigation of the physiological factors contributing to injury in relation to their influence on the mechanical properties that govern the reslience of the various tissues that make up the body. The proposed framework calls for changes in the manner that research hypotheses, research questions and study methodologies are formed, which will be explored below. Further, these changes will inevitably impact upon data analysis methods. Currently, injury research with origins in physiological variables often neglects the importance of mechanical functioning to injury occurrence and causal pathways are poorly understood. This has resulted in the disregard of certain fundamental principles that contribute to injury occurrence. Current practises commonly establish associations between physiological findings and injury outcomes without any consideration of the core mechanical reasonings behind the injury. These research practises restrict causation establishment as they are not conceptually linked to the mechanisms behind injury occurrence which are firmly grounded in both physiology and mechanics, along with the complex interactions between the two. Without establishing a cause-effect relation it is not possible to provide any practical recommendations, although this is erroneously commonly done.

\subsection{Implications for athletic injury research hypotheses and questions}

The proposed conceptual model and framework are comprised of considerably more detail for injury relative to most current research practices. They are also relevant for shifting hypotheses generation and deriving research questions regarding athletic injury. The current approaches to athletic injury research tend to frame their research questions rather simplistically, exploring whether a specific group presenting with a specific variable is at an elevated risk of injury. Recently, Bertelson et al. [2] argued that these forms of research questions are obsolete in modern sports injury research and a shift away from prediction and towards causation and intervention is needed. Research questions and hypotheses should centre on the core fundamental principles of tissue failure and injury occurrence, being an interplay between the stress and strain experienced due to an applied force, and specific tissue resilience. Studies incorporating physiological factors should acknowledge, and focus on, the influence of these factors on the mechanical properties that govern the load capacities of specific bodily tissues. As such, research questions and hypotheses for research studies centred on a particular physiological injury risk factor should be directed towards their influence on the applied forces experienced and the distribution of these forces across specific tissues, the tissue-specific stresses and strain experienced, and tissue resilience. Research questions and hypotheses formed in such a manner would incorporate multiple 
levels of the simple conceptual model and detailed conceptual framework. Specifically, they would effectively encapsulate the interplay between the physiological and mechanical factors involved in any stress or strain related injury occurences and therefore strongly directs physiologically oriented injury research towards a more holistic exploration of injury causation and prevention. This is an essential component of understanding causation and the development of effective intervention protocols.

\subsection{Implications for research methodologies and data collection procedures}

Considering the proposed framework suggests a shift in the formation of research hypotheses and research questions to be more explanatory of injury causation, this impacts upon the methodologies of future injury research. This framework emphasises that a simple predictive or factorial identification research design is largely inadequate and it is important for research to migrate towards a causation and interventional approach. Injury research should not simply explore risk factors as they relate to injury, rather designs should include research methodologies that are focused upon the determination of the various links within the framework for example, the effect of a specific variable on the material strength of a particular tissue. Studies incorporating these types of methodologies provide a substantially more explanative approach of the injury causation.

The change in methodological approach requires a transition in data collection procedures. The framework proposes that the mere collection of physiological data without the resulting mechanical data in many ways falls short of an effective research study aimed at understanding causation. As such, data collection procedures for studies considering injury need to be centred upon the related physiological factors assessed and their influence on the mechanical properties and load tolerances of the various structures within the body (Part A \& B). Alternatively, research exploring the external factors contributing to injury should seek to analyze both the mechanical properties of the body in relation to the external forces applied and the internal stresses and strains experienced (Part C \& D). Although substantial resources in time, expertise and equipment are required to establish a thorough understanding of a specific variable across the entire framework, incorporating measurements pertaining to parts $A$ to $F$ is ideal for injury research. This would fully encapsulate the interplay between the physiological characteristics of the body, the mechanical properties of the body, and the stresses and strains experienced by the various tissues that result in injury, vastly improving the interpretations to eminate from the research. It is noted that the logistics of conducting such in depth studies are extremely challenging. Regardless, where application of the framework in its entirety is not possible, research studies should seek to identify as many links presented within the framework as possible. Adhering to the pathways related to injury causation presented in the framework will assist researchers to develop understandings of how certain risk factors contribute to injury incidence to allow for accurate and thorough interpretations of research findings.

\subsection{CONCLUSION}

To date, a detailed framework outlining the causal pathways of specific risk factors for injury occurrence has not been established. The proposed framework provides a holistic understanding of injury occurrence centred around the concepts of load tolerance and load application. The framework considers both the physiological and mechanical characteristics of the human body whilst also incorporating the external forces applied that when excessive, result in injury. Notably, mechanical properties of the human body dictate the amount of stress and strain that the various structures within can withstand without being subjected to injury. Of further consideration are the differences in loading patterns that are experienced by particular structures as these largely determine the type of injury experienced. We recommend that future research attempts to move away from injury associations, focusing rather on researching injury causal pathways using this framework as a guide. Finally, it is important to reiterate that this is a proposal and future studies should seek to challenge the framework by confirming or dismissing the individual components.

\section{GLOSSARY}

Stress: Force per unit area that develops within a structure in response to externally applied loads. The stress may be tensile or compressive depending on the mode of loading. The stress may also be normal (changing the length in a structure) or shear (changing the angle in a structure) [181].

Strain: Deformation that occurs at a point in a structure under loading. Two basic types of strain exist: normal 
strain, which is a change in length, and shear strain, which is a change in angle. Normal strain is the ratio of deformation (lengthening or shortening) to original length. Shear strain is the amount of angular deformation that occurs in a structure. For example, a rectangle drawn on one face of a solid before a shear stress is applied will appear as a parallelogram during the application of a shear stress [181].

Stiffness: Stiffness effectively describes the relationship between a given force and the deformation of an object or body and particularly refers to the property of a material or system to resist an applied stretch $[182,183]$.

Young's modulus: The ratio of stress to strain at any point in the elastic region of deformation, yielding a value for stiffness. The stiffer the material, the higher the modulus [181].

Cyclic loading: The application of repeated or fluctuating stresses, strains, or stress intensities to locations on structural components.

Fatigue failure: The failure of a material or tissue caused by cyclic loading and material fatigue.

Hooke's Law: The strain in a material or solid is proportional to the applied stress within the elastic limit of that solid.

\section{REFERENCES}

1. Bahr R, Krosshaug T. Understanding injury mechanisms: a key component of preventing injuries in sport. Br J Sports Med. 2005 Jun;39(6):324-9.

2. Bertelsen ML, Hulme A, Petersen J, Brund RK, Sorensen $\mathrm{H}$, Finch $\mathrm{CF}$, et al. A framework for the etiology of running-related injuries. Scand J Med Sci Sports. 2017 Nov;27(11):1170-80.

3. McIntosh AS. Risk compensation, motivation, injuries, and biomechanics in competitive sport. Br J Sports Med. 2005 Jan;39(1):2-3.

4. Meeuwisse WH. Assessing causation in sport injury: a multifactorial model. Clin J Sport Med. 1994(4):166-70.

5. Meeuwisse WH, Tyreman H, Hagel B, Emery C. A dynamic model of etiology in sport injury: the recursive nature of risk and causation. Clin J Sport Med. 2007 May;17(3):215-9.

6. Shrier I, Steele RJ, Zhao M, Naimi A, Verhagen E,

Stovitz SD, et al. A multistate framework for the analysis of subsequent injury in sport (M-FASIS). Scand J Med Sci Sports. 2016 Feb;26(2):128-39.

7. Windt J, Gabbett TJ. How do training and competition workloads relate to injury? The workload-injury aetiology model. $\mathrm{Br}$ J Sports Med. 2017 Mar;51(5):428-35.

8. Edwards WB. Modeling Overuse Injuries in Sport as a Mechanical Fatigue Phenomenon. Exerc Sport Sci Rev. 2018 Oct;46(4):224-31.
9. Peterson RJAB. Discussion of a century ago concerning the nature of fatigue, and review of some of the subsequent researches concerning the mechanism of fatigue. 1950;164:50-6.

10. Lieber RL, Friden J. Muscle damage is not a function of muscle force but active muscle strain. J Appl Physiol (1985). 1993 Feb;74(2):520-6.

11. Garrett WE, Jr. Muscle strain injuries. Am J Sports Med. 1996;24(6 Suppl):S2-8.

12. Crossley K, Bennell KL, Wrigley T, Oakes BW. Ground reaction forces, bone characteristics, and tibial stress fracture in male runners. Med Sci Sports Exerc. 1999 Aug;31(8):1088-93.

13. Fung YC. Biomechanics : mechanical properties of living tissues. New York: Springer-Verlag; 1981.

14. Fung YC. Biomechanics : mechanical properties of living tissues. 2nd ed. New York: Springer-Verlag; 1993.

15. Hooke R. Lectures de potentia restitutiva, or of spring explaining the power of springing bodies: John Martyn; 2016.

16. Ekstrand J, Walden M, Hagglund M. Hamstring injuries have increased by $4 \%$ annually in men's professional football, since 2001: a 13-year longitudinal analysis of the UEFA Elite Club injury study. Br J Sports Med. 2016 Jun;50(12):731-7.

17. Elliott MC, Zarins B, Powell JW, Kenyon CD. Hamstring muscle strains in professional football players: a 10-year review. Am J Sports Med. 2011 Apr;39(4):843-50.

18. Hoskins WT, Pollard HP. Successful management of hamstring injuries in Australian Rules footballers: two case reports. Chiropr Osteopat. 2005 Apr 12;13(1):4.

19. Orchard JW, Seward H, Orchard JJ. Results of 2 decades of injury surveillance and public release of data in the Australian Football League. Am J Sports Med. 2013 Apr;41(4):734-41.

20. Colberg RE, Aune KT, Choi AJ, Fleisig GS. Incidence and Prevalence of Musculoskeletal Conditions in Collegiate Tennis Athletes. J Med Sci Tennis. 2015;20(3).

21. Moore IS, Ranson C, Mathema P. Injury Risk in International Rugby Union: Three-Year Injury Surveillance of the Welsh National Team. Orthop J Sports Med. 2015 Jul;3(7):2325967115596194.

22. Pollock N, Patel A, Chakraverty J, Suokas A, James SL, Chakraverty R. Time to return to full training is delayed and recurrence rate is higher in intratendinous ('c') acute hamstring injury in elite track and field athletes: clinical application of the British Athletics Muscle Injury Classification. Br J Sports Med. 2016 Mar;50(5):305-10.

23. Garrett WE, Jr., Safran MR, Seaber AV, Glisson RR, Ribbeck BM. Biomechanical comparison of stimulated and nonstimulated skeletal muscle pulled to failure. Am J Sports Med. 1987 Sep-Oct;15(5):448-54.

24. Hakkinen K, Keskinen KL. Muscle cross-sectional area and voluntary force production characteristics in elite strength- and endurance-trained athletes and sprinters. Eur J Appl Physiol Occup Physiol. 1989;59(3):215-20.

25. Hakkinen K, Alen M, Komi PV. Changes in isometric force- and relaxation-time, electromyographic and muscle fibre characteristics of human skeletal muscle during strength training and detraining. Acta Physiol Scand. 1985 Dec;125(4):573-85.

26. Hakkinen K, Komi PV. Electromyographic changes during strength training and detraining. Med Sci Sports Exerc. 1983;15(6):455-60.

27. Hortobagyi T, Houmard JA, Stevenson JR, Fraser DD, Johns RA, Israel RG. The effects of detraining on power athletes. Med Sci Sports Exerc. 1993 Aug;25(8):929-35.

28. de Hoyo M, Pozzo M, Sanudo B, Carrasco L, GonzaloSkok O, Dominguez-Cobo S, et al. Effects of a 10-week in-season eccentric-overload training program on muscle-injury prevention and performance in junior elite soccer players. Int J Sports Physiol Perform. 2015 Jan;10(1):46-52.

29. Cook CJ, Beaven CM, Kilduff LP. Three weeks of eccentric training combined with overspeed exercises enhances power and running speed performance gains in trained athletes. $\mathbf{J}$ Strength Cond Res. 2013 May;27(5):1280-6. 
30. Wen DY, Puffer JC, Schmalzried TP. Lower extremity alignment and risk of overuse injuries in runners. Med Sci Sports Exerc. 1997 Oct;29(10):1291-8.

31. Nielsen RO, Bertelsen ML, Parner ET, Sorensen H, Lind M, Rasmussen S. Running more than three kilometers during the first week of a running regimen may be associated with increased risk of injury in obese novice runners. Int J Sports Phys Ther. 2014 May;9(3):338-45.

32. Theisen D, Malisoux L, Genin J, Delattre N, Seil R, Urhausen A. Influence of midsole hardness of standard cushioned shoes on running-related injury risk. Br J Sports Med. 2014 Mar;48(5):371-6.

33. Buist I, Bredeweg SW, Lemmink KA, van Mechelen W, Diercks RL. Predictors of running-related injuries in novice runners enrolled in a systematic training program: a prospective cohort study. Am J Sports Med. 2010 Feb;38(2):273-80.

34. Taunton JE, Ryan MB, Clement DB, McKenzie DC, Lloyd-Smith DR, Zumbo BD. A retrospective case-control analysis of 2002 running injuries. Br J Sports Med. 2002 Apr;36(2):95-101. 35. Taunton JE, Ryan MB, Clement DB, McKenzie DC, Lloyd-Smith DR, Zumbo BD. A prospective study of running injuries: the Vancouver Sun Run "In Training" clinics. Br J Sports Med. 2003 Jun;37(3):239-44.

36. Buist I, Bredeweg SW, Bessem B, van Mechelen W, Lemmink KA, Diercks RL. Incidence and risk factors of runningrelated injuries during preparation for a 4-mile recreational running event. Br J Sports Med. 2010 Jun;44(8):598-604.

37. Kluitenberg B, van der Worp H, Huisstede BM, Hartgens F, Diercks R, Verhagen E, et al. The NLstart2run study: Trainingrelated factors associated with running-related injuries in novice runners. J Sci Med Sport. 2016 Aug;19(8):642-6.

38. SK G, JR E, R K, al. e. Bone mass, external loads, and stress fracture in female runners. J Appl Biomech. 1991;7(3).

39. Myburgh KH, Hutchins J, Fataar AB, Hough SF, Noakes TD. Low bone density is an etiologic factor for stress fractures in athletes. Ann Intern Med. 1990 Nov 15;113(10):754-9.

40. Kelsey JL, Bachrach LK, Procter-Gray E, Nieves J, Greendale GA, Sowers M, et al. Risk factors for stress fracture among young female cross-country runners. Med Sci Sports Exerc. 2007 Sep;39(9):1457-63.

41. Timmins RG, Shield AJ, Williams MD, Lorenzen C, Opar DA. Architectural adaptations of muscle to training and injury: a narrative review outlining the contributions by fascicle length pennation angle and muscle thickness. Br J Sports Med. 2016 Dec;50(23):1467-72.

42. Bourne MN, Duhig SJ, Timmins RG, Williams MD, Opar DA, Al Najjar A, et al. Impact of the Nordic hamstring and hip extension exercises on hamstring architecture and morphology: implications for injury prevention. $\mathrm{Br}$ J Sports Med. 2017 Mar;51(5):469-77.

43. Timmins RG, Shield AJ, Williams MD, Lorenzen C, Opar DA. Biceps femoris long head architecture: a reliability and retrospective injury study. Med Sci Sports Exerc. 2015 May;47(5):905-13.

44. Timmins RG, Bourne MN, Shield AJ, Williams MD Lorenzen C, Opar DA. Short biceps femoris fascicles and eccentric knee flexor weakness increase the risk of hamstring injury in elite football (soccer): a prospective cohort study. Br J Sports Med. 2016 Dec;50(24):1524-35

45. Morgan DL. New insights into the behavior of muscle during active lengthening. Biophys J. 1990 Feb;57(2):209-21.

46. Brockett CL, Morgan DL, Proske U. Predicting hamstring strain injury in elite athletes. Med Sci Sports Exerc. 2004 Mar;36(3):379-87.

47. Kongsgaard M, Aagaard P, Kjaer M, Magnusson SP Structural Achilles tendon properties in athletes subjected to different exercise modes and in Achilles tendon rupture patients. J Appl Physiol (1985). 2005 Nov;99(5):1965-71.

48. Magnusson SP, Narici MV, Maganaris CN, Kjaer M. Human tendon behaviour and adaptation, in vivo. J Physiol. 2008 Jan 1;586(1):71-81.
49. McKelvie SJ, Valliant PM, Asu ME. Physical training and personality factors as predictors of marathon time and training injury. Percept Mot Skills. 1985 Apr;60(2):551-66.

50. Hootman JM, Macera CA, Ainsworth BE, Martin M, Addy CL, Blair SN. Predictors of lower extremity injury among recreationally active adults. Clin J Sport Med. 2002 Mar;12(2):99106

51. Satterthwaite P, Norton R, Larmer P, Robinson E. Risk factors for injuries and other health problems sustained in a marathon. Br J Sports Med. 1999 Feb;33(1):22-6.

52. McKean KA, Manson NA, Stanish WD. Musculoskeletal injury in the masters runners. Clin J Sport Med. 2006 Mar;16(2):14954.

53. Messier SP, Edwards DG, Martin DF, Lowery RB, Cannon DW, James MK, et al. Etiology of iliotibial band friction syndrome in distance runners. Med Sci Sports Exerc. 1995 Jul;27(7):951-60.

54. Valliant PM. Personality and injury in competitive runners. Percept Mot Skills. 1981 Aug;53(1):251-3.

55. Duffey MJ, Martin DF, Cannon DW, Craven T, Messier SP. Etiologic factors associated with anterior knee pain in distance runners. Med Sci Sports Exerc. 2000 Nov;32(11):1825-32.

56. Walter SD, Hart LE, McIntosh JM, Sutton JR. The Ontario cohort study of running-related injuries. Arch Intern Med. 1989 Nov;149(11):2561-4.

57. Rasmussen CH, Nielsen RO, Juul MS, Rasmussen S. Weekly running volume and risk of running-related injuries among marathon runners. Int J Sports Phys Ther. 2013 Apr;8(2):111-20.

58. Marti B. Benefits and risks of running among women: an epidemiologic study. Int J Sports Med. 1988 Apr;9(2):92-8.

59. Marti B, Vader JP, Minder CE, Abelin T. On the epidemiology of running injuries. The 1984 Bern Grand-Prix study. Am J Sports Med. 1988 May-Jun;16(3):285-94.

60. Parker DT, Weitzenberg TW, Amey AL, Nied RJ. Group training programs and self-reported injury risk in female marathoners. Clin J Sport Med. 2011 Nov;21(6):499-507.

61. Reinking MF, Austin TM, Hayes AM. Exercise-related leg pain in collegiate cross-country athletes: extrinsic and intrinsic risk factors. J Orthop Sports Phys Ther. 2007 Nov;37(11):670-8.

62. Bennett JE, Reinking MF, Rauh MJ. The relationship between isotonic plantar flexor endurance, navicular drop, and exercise-related leg pain in a cohort of collegiate cross-country runners. Int J Sports Phys Ther. 2012 Jun;7(3):267-78.

63. Malisoux L, Ramesh J, Mann R, Seil R, Urhausen A, Theisen D. Can parallel use of different running shoes decrease running-related injury risk? Scand J Med Sci Sports. 2015 Feb;25(1):110-5.

64. Hirschmuller A, Frey V, Konstantinidis L, Baur H, Dickhuth HH, Sudkamp NP, et al. Prognostic value of Achilles tendon Doppler sonography in asymptomatic runners. Med Sci Sports Exerc. 2012 Feb;44(2):199-205.

65. Wen DY, Puffer JC, Schmalzried TP. Injuries in runners: a prospective study of alignment. Clin J Sport Med. 1998 Jul;8(3):187-94.

66. Nielsen RO, Buist I, Parner ET, Nohr EA, Sorensen H, Lind M, et al. Predictors of Running-Related Injuries Among 930 Novice Runners: A 1-Year Prospective Follow-up Study. Orthop J Sports Med. 2013 Jan-Jun;1(1):2325967113487316.

67. Macera CA, Pate RR, Powell KE, Jackson KL, Kendrick JS, Craven TE. Predicting lower-extremity injuries among habitual runners. Arch Intern Med. 1989 Nov;149(11):2565-8.

68. Lloyd T, Triantafyllou SJ, Baker ER, Houts PS, Whiteside JA, Kalenak A, et al. Women athletes with menstrual irregularity have increased musculoskeletal injuries. Med Sci Sports Exerc. 1986 Aug;18(4):374-9.

69. Barrow GW, Saha S. Menstrual irregularity and stress fractures in collegiate female distance runners. Am J Sports Med. 1988 May-Jun;16(3):209-16.

70. Kannus P, Natri A. Etiology and pathophysiology of tendon ruptures in sports. Scand J Med Sci Sports. 1997 Apr;7(2):107-12. 
71. Souryal TO, Freeman TR. Intercondylar notch size and anterior cruciate ligament injuries in athletes. A prospective study. Am J Sports Med. 1993 Jul-Aug;21(4):535-9.

72. LaPrade RF, Burnett QM, 2nd. Femoral intercondylar notch stenosis and correlation to anterior cruciate ligament injuries A prospective study. Am J Sports Med. 1994 Mar-Apr;22(2):198202; discussion 3 .

73. Knobloch K, Yoon U, Vogt PM. Acute and overuse injuries correlated to hours of training in master running athletes. Foot Ankle Int. 2008 Jul;29(7):671-6.

74. Messier SP, Davis SE, Curl WW, Lowery RB, Pack RJ. Etiologic factors associated with patellofemoral pain in runners. Med Sci Sports Exerc. 1991 Sep;23(9):1008-15

75. Haglund-Akerlind Y, Eriksson E. Range of motion, muscle torque and training habits in runners with and withou Achilles tendon problems. Knee Surg Sports Traumatol Arthrosc. 1993;1(3-4):195-9.

76. Caselli MA, Longobardi SJ. Lower extremity injuries a the New York City Marathon. J Am Podiatr Med Assoc. 1997 Jan;87(1):34-7.

77. McQuade KJ. A Case-Control Study of Running Injuries: Comparison of Patterns-of Runners With and Without Running Injuries. J Orthop Sports Phys Ther. 1986;8(2):81-4.

78. Jacobs SJ, Berson BL. Injuries to runners: a study of entrants to a 10,000 meter race. Am J Sports Med. 1986 MarApr;14(2):151-5.

79. van Reijen M, Vriend I, van Mechelen W, Finch CF, Verhagen EA. Compliance with Sport Injury Prevention Interventions in Randomised Controlled Trials: A Systematic Review. Sports Med. 2016 Aug;46(8):1125-39.

80. Marti B, Rehmann R. Determinants of physician visit rates among joggers: multivariate analysis of 4000 participants in a popular race. Soz Praventivmed. 1987;32(4-5):204-6.

81. Chang WL, Shih YF, Chen WY. Running injuries and associated factors in participants of ING Taipei Marathon. Phys Ther Sport. 2012 Aug;13(3):170-4.

82. Hespanhol Junior LC, Pena Costa LO, Lopes AD. Previous injuries and some training characteristics predict runningrelated injuries in recreational runners: a prospective cohort study. $\mathrm{J}$ Physiother. 2013 Dec;59(4):263-9.

83. McCrory JL, Martin DF, Lowery RB, Cannon DW, Curl WW, Read HM, Jr., et al. Etiologic factors associated with Achilles tendinitis in runners. Med Sci Sports Exerc. 1999 Oct;31(10):137481.

84. Askling C, Karlsson J, Thorstensson A. Hamstring injury occurrence in elite soccer players after preseason strength training with eccentric overload. Scand J Med Sci Sports. 2003 Aug;13(4):244-50.

85. Chimera NJ, Swanik KA, Swanik CB, Straub SJ. Effects of Plyometric Training on Muscle-Activation Strategies and Performance in Female Athletes. J Athl Train. 2004 Mar;39(1):2431.

86. Gabbett TJ, Jenkins DG. Relationship between training load and injury in professional rugby league players. J Sci Med Sport. 2011 May;14(3):204-9.

87. Hewett TE, Stroupe AL, Nance TA, Noyes FR. Plyometric training in female athletes. Decreased impact forces and increased hamstring torques. Am J Sports Med. 1996 NovDec;24(6):765-73.

88. Myer GD, Ford KR, McLean SG, Hewett TE. The effects of plyometric versus dynamic stabilization and balance training on lower extremity biomechanics. Am J Sports Med. 2006 Mar;34(3):445-55.

89. Opar DA, Williams MD, Timmins RG, Hickey J, Duhig SJ, Shield AJ. Eccentric hamstring strength and hamstring injury risk in Australian footballers. Med Sci Sports Exerc. 2015 Apr;47(4):857-65.

90. Timmins RG, Ruddy JD, Presland J, Maniar N, Shield AJ, Williams MD, et al. Architectural Changes of the Biceps Femoris Long Head after Concentric or Eccentric Training. Med Sci Sports Exerc. 2016 Mar;48(3):499-508.
91. Behm DG, Blazevich AJ, Kay AD, McHugh M. Acute effects of muscle stretching on physical performance, range of motion, and injury incidence in healthy active individuals: a systematic review. Appl Physiol Nutr Metab. 2016 Jan;41(1):1-11. 92. Cobb KL, Bachrach LK, Sowers M, Nieves J, Greendale GA, Kent KK, et al. The effect of oral contraceptives on bone mass and stress fractures in female runners. Med Sci Sports Exerc. 2007 Sep;39(9):1464-73.

93. Fullagar HH, Duffield R, Skorski S, Coutts AJ, Julian R, Meyer T. Sleep and Recovery in Team Sport: Current Sleep-Related Issues Facing Professional Team-Sport Athletes. Int J Sports Physiol Perform. 2015 Nov;10(8):950-7.

94. Fullagar HH, Skorski S, Duffield R, Hammes D, Coutts AJ, Meyer T. Sleep and athletic performance: the effects of sleep loss on exercise performance, and physiological and cognitive responses to exercise. Sports Med. 2015 Feb;45(2):161-86.

95. Milewski MD, Skaggs DL, Bishop GA, Pace JL, Ibrahim DA, Wren TA, et al. Chronic lack of sleep is associated with increased sports injuries in adolescent athletes. J Pediatr Orthop. 2014 Mar;34(2):129-33.

96. Duclay J, Martin A, Duclay A, Cometti G, Pousson M. Behavior of fascicles and the myotendinous junction of human medial gastrocnemius following eccentric strength training. Muscle Nerve. 2009 Jun;39(6):819-27.

97. Kongsgaard M, Reitelseder S, Pedersen TG, Holm L, Aagaard P, Kjaer $\mathrm{M}$, et al. Region specific patellar tendon hypertrophy in humans following resistance training. Acta Physiol (Oxf). 2007 Oct;191(2):111-21.

98. Shadwick RE. Elastic energy storage in tendons: mechanical differences related to function and age. J Appl Physiol (1985). 1990 Mar;68(3):1033-40.

99. Grosset JF, Breen L, Stewart CE, Burgess KE, Onambele GL. Influence of exercise intensity on training-induced tendon mechanical properties changes in older individuals. Age (Dordr). 2014 Jun;36(3):9657.

100. Malliaras P, Kamal B, Nowell A, Farley T, Dhamu H, Simpson V, et al. Patellar tendon adaptation in relation to loadintensity and contraction type. J Biomech. 2013 Jul 26;46(11):18939 .

101. Reeves ND, Narici MV, Maganaris CN. Strength training alters the viscoelastic properties of tendons in elderly humans. Muscle Nerve. 2003 Jul;28(1):74-81

102. Seynnes OR, Erskine RM, Maganaris CN, Longo S, Simoneau EM, Grosset JF, et al. Training-induced changes in structural and mechanical properties of the patellar tendon are related to muscle hypertrophy but not to strength gains. J Appl Physiol (1985). 2009 Aug;107(2):523-30.

103. Kubo K, Morimoto M, Komuro T, Yata H, Tsunoda N, Kanehisa H, et al. Effects of plyometric and weight training on muscle-tendon complex and jump performance. Med Sci Sports Exerc. 2007 Oct;39(10):1801-10.

104. Macaluso A, De Vito G. Muscle strength, power and adaptations to resistance training in older people. Eur J Appl Physiol. 2004 Apr;91(4):450-72.

105. Andersen LL, Tufekovic G, Zebis MK, Crameri RM,

Verlaan G, Kjaer M, et al. The effect of resistance training combined with timed ingestion of protein on muscle fiber size and muscle strength. Metabolism. 2005 Feb;54(2):151-6.

106. Anderson T, Kearney JT. Effects of three resistance training programs on muscular strength and absolute and relative endurance. Res Q Exerc Sport. 1982 Mar;53(1):1-7.

107. Turner CH. Bone strength: current concepts. Ann N Y Acad Sci. 2006 Apr;1068:429-46.

108. Robling AG, Hinant FM, Burr DB, Turner CH. Improved bone structure and strength after long-term mechanical loading is greatest if loading is separated into short bouts. J Bone Miner Res. 2002 Aug; 17(8):1545-54.

109. Komi PV. Training of muscle strength and power: interaction of neuromotoric, hypertrophic, and mechanical factors. Int J Sports Med. 1986 Jun;7 Suppl 1:10-5.

110. Houk JC. Feedback control of muscle: a synthesis of the 
peripheral mechanisms, in Mountcastle W.B. (ed). Medical Physiology (13th ed): St. Louis Mo, Mosby; 1974. p. 668-77. 111. Edman KA, Lou F. Changes in force and stiffness induced by fatigue and intracellular acidification in frog muscle fibres. J Physiol. 1990 May;424:133-49.

112. Chamari K, Haddad M, Wong del P, Dellal A, Chaouachi A. Injury rates in professional soccer players during Ramadan. J Sports Sci. 2012;30 Suppl 1:S93-102.

113. Dugan SA, Frontera WR. Muscle fatigue and muscle injury. Phys Med Rehabil Clin N Am. 2000 May;11(2):385-403.

114. Garrett WE, Jr., Califf JC, Bassett FH, 3rd. Histochemical correlates of hamstring injuries. Am J Sports Med. 1984 MarApr;12(2):98-103.

115. Yamamoto T. Relationship between hamstring strains and leg muscle strength. A follow-up study of collegiate track and field athletes. J Sports Med Phys Fitness. 1993 Jun;33(2):194-9.

116. Orchard J, Marsden J, Lord S, Garlick D. Preseason hamstring muscle weakness associated with hamstring muscle injury in Australian footballers. Am J Sports Med. 1997 Jan-Feb;25(1):815 .

117. Heiser TM, Weber J, Sullivan G, Clare P, Jacobs RR. Prophylaxis and management of hamstring muscle injuries in intercollegiate football players. Am J Sports Med. 1984 SepOct;12(5):368-70.

118. Burkett LN. Investigation into hamstring strains: the case of the hybrid muscle. J Sports Med. 1975 Sep-Oct;3(5):228-31.

119. Baumhauer JF, Alosa DM, Renstrom AF, Trevino S Beynnon B. A prospective study of ankle injury risk factors. Am J Sports Med. 1995 Sep-Oct;23(5):564-70.

120. Croisier JL, Ganteaume S, Binet J, Genty M, Ferret JM Strength imbalances and prevention of hamstring injury in professional soccer players: a prospective study. Am J Sports Med. 2008 Aug;36(8):1469-75.

121. Ekstrand J, Gillquist J. Soccer injuries and their mechanisms: a prospective study. Med Sci Sports Exerc 1983;15(3):267-70.

122. Fousekis K, Tsepis E, Poulmedis P, Athanasopoulos S, Vagenas G. Intrinsic risk factors of non-contact quadriceps and hamstring strains in soccer: a prospective study of 100 professional players. Br J Sports Med. 2011 Jul;45(9):709-14.

123. Soderman K, Alfredson H, Pietila T, Werner S. Risk factors for leg injuries in female soccer players: a prospective investigation during one out-door season. Knee Surg Sports Traumatol Arthrosc. 2001 Sep;9(5):313-21.

124. Sugiura Y, Saito T, Sakuraba K, Sakuma K, Suzuki E. Strength deficits identified with concentric action of the hip extensors and eccentric action of the hamstrings predispose to hamstring injury in elite sprinters. J Orthop Sports Phys Ther. 2008 Aug;38(8):457-64.

125. Yeung SS, Suen AM, Yeung EW. A prospective cohor study of hamstring injuries in competitive sprinters: preseason muscle imbalance as a possible risk factor. Br J Sports Med. 2009 Aug;43(8):589-94

126. Woods C, Hawkins RD, Maltby S, Hulse M, Thomas A, Hodson A, et al. The Football Association Medical Research Programme: an audit of injuries in professional football--analysis of hamstring injuries. Br J Sports Med. 2004 Feb;38(1):36-41.

127. Hrysomallis C. Relationship between balance ability, training and sports injury risk. Sports Med. 2007;37(6):547-56.

128. Emery CA, Cassidy JD, Klassen TP, Rosychuk RJ, Rowe $\mathrm{BH}$. Effectiveness of a home-based balance-training program in reducing sports-related injuries among healthy adolescents: a cluster randomized controlled trial. CMAJ. 2005 Mar 15;172(6):749-54.

129. Hewett TE, Myer GD, Ford KR, Heidt RS, Jr., Colosimo AJ, McLean SG, et al. Biomechanical measures of neuromuscular control and valgus loading of the knee predict anterior cruciate ligament injury risk in female athletes: a prospective study. Am J Sports Med. 2005 Apr;33(4):492-501.

130. Zazulak BT, Hewett TE, Reeves NP, Goldberg B, Cholewicki J. Deficits in neuromuscular control of the trunk predic knee injury risk: a prospective biomechanical-epidemiologic study. Am J Sports Med. 2007 Jul;35(7):1123-30.

131. Hewett TE, Zazulak BT, Myer GD, Ford KR. A review of electromyographic activation levels, timing differences, and increased anterior cruciate ligament injury incidence in female athletes. Br J Sports Med. 2005 Jun;39(6):347-50.

132. Campbell A, Straker L, O'Sullivan P, Elliott B, Reid M. Lumbar loading in the elite adolescent tennis serve: link to low back pain. Med Sci Sports Exerc. 2013 Aug;45(8):1562-8.

133. Elliott BC. Back injuries and the fast bowler in cricket. J Sports Sci. 2000 Dec;18(12):983-91.

134. Portus M, Mason BR, Elliott BC, Pfitzner MC, Done RP. Technique factors related to ball release speed and trunk injuries in high performance cricket fast bowlers. Sports Biomech. 2004 Jul;3(2):263-84.

135. Cavanagh PR, Lafortune MA. Ground reaction forces in distance running. J Biomech. 1980;13(5):397-406.

136. Scott SH, Winter DA. Internal forces of chronic running injury sites. Med Sci Sports Exerc. 1990 Jun;22(3):357-69.

137. Brooks JH, Fuller CW, Kemp SP, Reddin DB. Epidemiology of injuries in English professional rugby union: part 1 match injuries. Br J Sports Med. 2005 Oct;39(10):757-66.

138. Brooks JH, Fuller CW, Kemp SP, Reddin DB. Epidemiology of injuries in English professional rugby union: part 2 training Injuries. Br J Sports Med. 2005 Oct;39(10):767-75.

139. Fuller CW, Brooks JH, Cancea RJ, Hall J, Kemp SP. Contact events in rugby union and their propensity to cause injury. Br J Sports Med. 2007 Dec;41(12):862-7; discussion 7.

140. Boden BP, Dean GS, Feagin JA, Jr., Garrett WE, Jr. Mechanisms of anterior cruciate ligament injury. Orthopedics. 2000 Jun;23(6):573-8.

141. Powell JW, Schootman M. A multivariate risk analysis of selected playing surfaces in the National Football League: 1980 to 1989. An epidemiologic study of knee injuries. Am J Sports Med. 1992 Nov-Dec;20(6):686-94.

142. Arnason A, Gudmundsson A, Dahl HA, Johannsson E. Soccer injuries in Iceland. Scand J Med Sci Sports. 1996 Feb;6(1):40-5.

143. McKay GD, Goldie PA, Payne WR, Oakes BW. Ankle injuries in basketball: injury rate and risk factors. Br J Sports Med. 2001 Apr;35(2):103-8

144. McHugh PT, T. Muscle strain injury vs muscle damage: Two mutually exclusive clinical entities. Transl Sports Med. 2019;0(0):1-7.

145. Arampatzis A, Schade F, Walsh M, Bruggemann GP. Influence of leg stiffness and its effect on myodynamic jumping performance. J Electromyogr Kinesiol. 2001 Oct;11(5):355-64.

146. Dietz V, Schmidtbleicher D, Noth J. Neuronal mechanisms of human locomotion. J Neurophysiol. 1979 Sep;42(5):1212-22.

147. Gollhofer A, Schmidtbleicher D, Dietz V. Regulation of muscle stiffness in human locomotion. Int J Sports Med. 1984 Feb;5(1):19-22.

148. Hoffer JA, Andreassen S. Regulation of soleus muscle stiffness in premammillary cats: intrinsic and reflex components. J Neurophysiol. $1981 \mathrm{Feb}$;45(2):267-85.

149. Kuitunen S, Komi PV, Kyrolainen H. Knee and ankle joint stiffness in sprint running. Med Sci Sports Exerc. 2002 Jan;34(1):166-73.

150. Friden J, Lieber RL. Structural and mechanical basis of exercise-induced muscle injury. Med Sci Sports Exerc. 1992 May;24(5):521-30.

151. Lovering RM, Hakim M, Moorman CT, 3rd, De Deyne PG. The contribution of contractile pre-activation to loss of function after a single lengthening contraction. J Biomech. 2005 Jul;38(7):1501-7.

152. Talbot JA, Morgan DL. The effects of stretch parameters on eccentric exercise-induced damage to toad skeletal muscle. $\mathbf{J}$ Muscle Res Cell Motil. 1998 Apr;19(3):237-45. 
153. Lieber RL, Woodburn TM, Friden J. Muscle damage induced by eccentric contractions of $25 \%$ strain. J Appl Physiol (1985). 1991 Jun;70(6):2498-507.

154. Milner CE, Ferber R, Pollard CD, Hamill J, Davis IS. Biomechanical factors associated with tibial stress fracture in female runners. Med Sci Sports Exerc. 2006 Feb;38(2):323-8.

155. Melvin JW. Fracture mechanics of bone. J Biomech Eng. 1993 Nov;115(4B):549-54

156. Galloway MT, Jokl P, Dayton OW. Achilles tendon overuse injuries. Clin Sports Med. 1992 Oct;11(4):771-82.

157. Burr DB, Milgrom C, Boyd RD, Higgins WL, Robin G, Radin EL. Experimental stress fractures of the tibia. Biological and mechanical aetiology in rabbits. J Bone Joint Surg Br. 1990 May;72(3):370-5.

158. Li GP, Zhang SD, Chen G, Chen H, Wang AM Radiographic and histologic analyses of stress fracture in rabbit tibias. Am J Sports Med. 1985 Sep-Oct;13(5):285-94.

159. Weightman B, Chappell DJ, Jenkins EA. A second study of tensile fatigue properties of human articular cartilage. Ann Rheum Dis. 1978 Feb;37(1):58-63.

160. Wren TA, Lindsey DP, Beaupre GS, Carter DR. Effects of creep and cyclic loading on the mechanical properties and failure of human Achilles tendons. Ann Biomed Eng. 2003 Jun;31(6):7107.

161. Carter DR, Caler WE. A cumulative damage model for bone fracture. J Orthop Res. 1985;3(1):84-90.

162. Fung DT, Wang VM, Laudier DM, Shine JH, BastaPljakic J, Jepsen KJ, et al. Subrupture tendon fatigue damage. J Orthop Res. 2009 Feb;27(2):264-73.

163. Herman BC, Cardoso L, Majeska RJ, Jepsen KJ, Schaffler MB. Activation of bone remodeling after fatigue: differential response to linear microcracks and diffuse damage. Bone. 2010 Oct;47(4):766-72.

164. Martin B. A theory of fatigue damage accumulation and repair in cortical bone. J Orthop Res. 1992 Nov;10(6):818-25.

165. Lenhart RL, Thelen DG, Wille CM, Chumanov ES, Heiderscheit BC. Increasing running step rate reduces patellofemora joint forces. Med Sci Sports Exerc. 2014 Mar;46(3):557-64.

166. Miner MA. Cumulative damage in fatigue. J Appl Mech. 1945;67:A159-64

167. Palmgren AJN. „Die Lebensdauer von Kugellagern,"VDI-Zeitschrift. 1924;58:339-41.

168. Stephens RI, Fatemi A, Stephens RR, Fuchs HO. Metal fatigue in engineering: John Wiley \& Sons; 2000.
169. Gallagher S, Heberger JR. Examining the interaction of force and repetition on musculoskeletal disorder risk: a systematic literature review. Hum Factors. 2013 Feb;55(1):108-24

170. Carter DR, Caler WE, Spengler DM, Frankel VH. Fatigue behavior of adult cortical bone: the influence of mean strain and strain range. Acta Orthop Scand. 1981 Oct;52(5):481-90.

171. Hunter I, Smith GA. Preferred and optimal stride frequency, stiffness and economy: changes with fatigue during a 1-h high-intensity run. Eur J Appl Physiol. 2007 Aug;100(6):653-61.

172. Gibala MJ, MacDougall JD, Tarnopolsky MA, Stauber

WT, Elorriaga A. Changes in human skeletal muscle ultrastructure and force production after acute resistance exercise. J Appl Physiol (1985). 1995 Feb;78(2):702-8.

173. Lieber RL, Friden J. Selective damage of fast glycolytic muscle fibres with eccentric contraction of the rabbit tibialis anterior. Acta Physiol Scand. 1988 Aug;133(4):587-8.

174. Friden J, Sjostrom M, Ekblom B. Myofibrillar damage following intense eccentric exercise in man. Int J Sports Med. 1983 Aug;4(3):170-6.

175. Schoenfeld BJ. Does exercise-induced muscle damage play a role in skeletal muscle hypertrophy? J Strength Cond Res. 2012 May;26(5):1441-53.

176. Friden J. Changes in human skeletal muscle induced by long-term eccentric exercise. Cell Tissue Res. 1984;236(2):365-72.

177. Bohm S, Mersmann F, Arampatzis A. Human tendon adaptation in response to mechanical loading: a systematic review and meta-analysis of exercise intervention studies on healthy adults. Sports Med Open. 2015 Dec;1(1):7.

178. Reeves ND. Adaptation of the tendon to mechanical usage. J Musculoskelet Neuronal Interact. 2006 Apr-Jun;6(2):17480 .

179. Burr DB, Martin RB, Schaffler MB, Radin EL. Bone remodeling in response to in vivo fatigue microdamage. J Biomech. 1985;18(3):189-200

180. Chamay A, Tschantz P. Mechanical influences in bone remodeling. Experimental research on Wolff's law. J Biomech. 1972 Mar;5(2):173-80.

181. Rodgers MM, Cavanagh PRJPT. Glossary of biomechanical terms, concepts, and units. 1984;64(12):1886-902.

182. Baumgart E. Stiffness--an unknown world of mechanical science? Injury. 2000 May;31 Suppl 2:S-B14-23.

183. Latash ML, Zatsiorsky VM. Joint stiffness: Myth or reality? Hum Mov Sci. 1993;12(6):653-92. 